DOI: $10.31558 / 2308-1902.2019 .27 .12$

Ольга ПУНІНА

кандидат філологічних наук, доцент, Донецький національний університет імені Василя Стуса

\title{
ОБОРОННА СИСТЕМА ВАСИЛЯ СТУСА: ЕТИКА І ТВОРЧИЙ ПРОЦЕС
}

\begin{abstract}
У статті об’єктом дослідження постає позиція оборони, в якій перебував Василь Стус як людина і творець. Ця позиція щодо реального (соціалістичного) світу розцінена за позицію типового інтроверта. В основі сформованої оборонної системи письменника покладено два ключових поняття - етика і творчий процес.

Ключові слова: етика, творчий процес, інтроверт, експресіоніст, епістолярій, спогади.
\end{abstract}

Постановка проблеми у загальному вигляді та іï зв'язок із важливими науковими чи практичними завданнями. Якщо спробувати дати ємку відповідь на питання, пов’язані з готовністю людської психіки діяти чи реагувати в певному напрямку, - як людина діє й орiєнmyєmься у свіmi?, як людина сприймає зовнішній подразник?, як людина реагує на изей подразник?, то беручи до уваги складники Стусової індивідуальної своєрідності (див. статтю [1]), що проявляється в рішеннях, почуттях, учинках, оцінках тощо, вона очевидна. Василь Стус діє, сприймає і реагує загострено / вразливо / експансивно, орієнтуючись на внутрішні особистісні фактори та, по суті, перманентно обороняючись - на багатьох рівнях: мовному, ментальному, світоглядному, фізичному. Невипадковим i чітко осмисленим тому сприймається Стусове: «Усе, Вальочку, гаразд. Я повен трагічного оптимізму, що світ - опроти мене - є собі, я ж - є собі - опроти нього» [2, с. 337], - із листа до дружини від 11 лютого 1979 року.

Постановка завдання. Позиція оборони, в якій перебуває Стус щодо реального (соціалістичного / історичного) світу - позиція типового інтроверта [13, с. 353], формує його специфічну оборонну систему - етичну, особливо коли зважити на той факт, що відстоювати власну позицію йому доводиться упродовж усього життя. «Моє ставлення до речей, - дає пояснення Василь 
Стус під час допиту 7 липня 1972 року щодо змісту окремих публіцистичних листів, зокрема «Місце в бою чи в розправі?», і доводить безпідставність закидів щодо «антирадянської діяльності» слідством, - завжди ставлення людини, яку насамперед обходить етика. Саме через це я не міг не висловити своєї думки, коли бачу, що покоління Івана Дзюби - людей, що виросли і здобули моральної, громадянської конституції в часи 20 і 22 з’їздів КПРС, стали цькувати люди типу Полторацького чи Дмитерка, ці типові представники культівського “громадянського” служіння. <...>.

Отже, захищаючи Дзюбу, я захищав моральну поведінку від неморальної. Бути полторацьким - завжди легко. Бути дзюбами - завжди тяжко, як завжди буває тяжко чесній, принциповій, порядній $і$ високоталановитій людині» (iз кримінальної справи № 47. Том 1; курсив мій. - О. П.) [3, с. 298].

Аналіз останніх досліджень і публікацій, в яких започатковано розв'язання даної проблеми i на які спирається автор. Як зазначає літературний критик і стусознавець Олег Соловей, у випадку з Василем Стусом етичний максималізм - це чітко визначена імперативність у царині етики загалом і власної поведінки. Даючи фахову оцінку книзі вибраних творів «Таборовий зошит», він зауважує, що для Стуса-поета «важила не сама лише здатність чесно померти, але й чесно прожити своє життя» [4, с. 51], а це, у свою чергу, приводить критика до думки про Стуса-експресіоніста та його модель боротьби. «Бути експресіоністом, - пише Олег Соловей, - для мистця минулого XX століття означало не так свідомий раціональний вибір, як неможливість якогось іншого шляху естетичного освоєння світу, іншої моделі боротьби та мучеництва за весь світ. Це нагадує шлях під тягарем хреста» (курсив автора. - О. П.) [4, с. 51].

\section{Виділення невиділених раніше частин загальної проблеми, яким} присвячується означена стаття. Важливо відзначити, що остаточне цементування оборонної системи Василя Стуса відбудеться після переламних подій у вересні-листопаді 1972 року - суд, принизливі для поета касаційна скарга i відкритий лист, та прийде 3 прийняттям «нового себе» й 
усвідомленням неможливості «порозумітися з владцями країни, яку він любив більше за самого себе» [3, с. 317]. За словами Дмитра Стуса, від нього вимагали розтоптати в собі людину, проте цього Василь Стус принципово зробити не міг.

Виклад основного матеріалу дослідження 3 повним обгрунтуванням отриманих наукових результатів. Наслідки оборонної системи в дії, своєрідного прояву Стусового психотизму, впродовж багатьох років наочно ілюструє вчинок, викладений у листах письменника до родини від 23 липня 1984 року і 1 серпня 1984 року, що писалися після невдалого побачення 3 Валентиною Попелюх, Дмитром Стусом і Марією Чередниченко. Йдеться про відмову 16 липня 1984 року від зустрічі з ними через принципову незгоду проходити принизливу процедуру обшуку i розмовляти нерідною (російською) мовою. Із липневого листа до рідних: «Дорогі мої, довше не писав до Вас. Усе сподівався, що напишу після побачення, коли таке буде. А вийшло, що до побачення мене не довели, тільки на третій день дали тютюн і 100 гр. якихось пермських цукерок. Ось і вже. Що вдієш - так уже є. Тут, мабуть, не побачимся з Вами до самого кінця, бо саме передпобачення обставлене всякими принизливими процедурами, подолати які мені з кожним днем стає все важче. Отож, хоч інші і проходять цей бар'єр, а я - не можу. Думаю, через те, що перетерпіла моя душа не може спокійно переносити найменшої образи.

$<\ldots>$ До всього тут треба на короткому побаченні розмовляти поросійськи, а я того і не уявляю - як би то я з Вами говорив нерідною мовою» [2, с. 468]. У серпневому листі до дружини Стус удруге пояснює: «Ось це, Вальочку, Еврідіка. Тобто - Ти. А Еврідіка - суть поемки Рільке, їі головна тема, така близька мені тепер, особливо після нашого не-побачення. Про той тяжкий день - 16 липня - я вже писав до мами, писав Тобі (за серпень), але листа повернули. Повторюю, Валю: бар’єр передпобаченнєвих принижень я не зміг подолати. I з кожним днем все тяжче мені на цьому світі, казав Вінграновський. Зараз я не певен (як і раніше), що ми побачимося. <..>. 
$<$...>. Вальочку, люба моя, повір мені - я не можу йти на побачення з Тобою (Тобою!), заплативши за зустріч самоприниженням, яке чомусь називають ритуалом. Отож, покладемося на Долю, довіримося їй» [2, с. 470 - 471].

Попри будь-що лишатися собою - тобто людиною, яка не терпить ані фізичного, ані морального знущання, - наскрізна думка двох листів, у яких Василь Стус удається і до викличного самохарактеризування. Непослух - так означує себе Василь Стус, звертаючись у липневому листі до сестри 3 пересторогою, аби на здійснений ним учинок не гнівалася дружина. Жорстоким він називає себе в наступному, серпневому, листі до Валентини Попелюх. Зрештою, саме ця Стусова відмова підкорятися кому-небудь і слухатися когось засвідчує його глибоку викінченість особи: «...Інакшим я не можу бути. А коли б був інакшим, то вже не був би собою» [2, с. 469].

Інший ракурс оборонної позиції Василя Стуса - творчий процес, який, за метафоричним коментарем письменника, $є$ його опертям в умовах постійної оборони. Звертаючись у листі від 13-17 червня 1975 року, адресованого батькам, до колеги-мистецтвознавця і перекладача аспірантських часів Юлія Шелеста, Стус пише: «Що ж до мови, Юлію, то Ти знову маєш рацію: дійсно, той світ образний, який $є$ по віршах, уже мусів би мені самому давно збридіти. Але за цих умов він - опертя моє, та стіна, яку я маю підпирати плечима, аби, обороняючись од трьох стін, знати, що бодай один бік надійний. Цей момент свідомого паразитування (вживаю заенергійне слово навмисне) Ти забуваєш чи просто вважав за краще його не торкатися. Отож, будь ласка, терпи, якщо й далі будуть іти старі мої тремти, свічада тощо. Без них я підвивав би потроху, а підвивати не хочу» [5, с. 150]. В умовах, які склалися, для Василя Стуса неабиякого значення набуває штучно сотворений суб’єктивний світ художній, відтак внутрішня реальність бачиться набагато важливішою. Як зауважує Михайло Осадчий, поезія для Василя Стуса в ув'язненні була психологічним рятунком і душевним відпруженням [6, с. 43]. Доречно в цьому контексті також згадати переконання Дмитра Стуса, текстолога і біографа: для 
Василя Стуса як людини з психологією справжнього поета (за поведінковим стереотипом) творче натхнення було важливішим за життєві негаразди.

Із психологічної позиції йдеться про рух психічної енергії автора в напрямку до внутрішнього світу - так, як працює механізм інтроверсії. Без того схильна до самотності, мовчазна і скромна натура Василя Стуса - за спостереженнями Генріха Дворка, він ніколи не розкривався [7, с. 207] - в становищі таборового ув'язнення, заслання максимально відсторонюється від реальності та сконцентровується на своїй творчій робітні, наскільки це дозволяють обставини. Невипадково той же близький товариш Генріх Дворко, говорячи про Стуса як неймовірно цільну людину, зауважує: «Він був направлений в одному напрямку якомусь. Ті вірші, які він написав, я не можу сам оцінити, хоча мені подобались вірші його, які він читав. Але їх не можна зіставити $з$ тим, що він почав там писати. Всі вважають, що він поетом став там, в тюрмі. Що, фактично, там його зробили поетом. Певна річ, він до цього йшов, він до цього готувався. Перед тим він став людиною. Всередині в нього ця енергія дуже сильно горіла» [7, с. 208].

Уже в перших грудневих листах Василя Стуса до родини з Мордовії чітко прочитується думка, своєрідна реакція на ув'язнення, про роки в таборі як час, що зможе дещо дати для розвитку, досвіду, творчості, і час - від якого він прагнутиме взяти все, що можна, - вивчати мови, читати, перекладати, працювати над собою [2, с. 10-11]. В умовах, за словами самого Стуса, його прекрасної катастрофи табірні вірші видаються кращими, аніж написані до цього. Про що йдеться у листі до батьків і дружини від 28-30 липня 1974 року, написаного поетом у статусі спещифічного переможия. Тут же - метафоричне прочитання Василем Стусом наперед визначеної і невідворотної ситуації, у якій перебуває: «Стояти над безоднею, чуючи легке запаморочення голови то куди цікавіша для мене творча ситуація, аніж нудитися в звалашеному київському творчому шарварку. I - крім усього - ми, бувши неакторами, не обираємо ситуацій. Ситуації обирають нас, і нам од того ні відхреститися, ні відмолитися, слава Богу» [2, с. 91]. 
Стояння над безоднею як неминуча творча ситуація для Василя Стуса це здатність в нестерпних, травмогенних, умовах побутово-приземленого перебування у ЖХ-385/3 селища Барашево та подібних установ у подальші роки, всупереч, реалізовувати свою мету і свій зміст, перебуваючи таким чином на своєрідній межі, зіткненні, лінії оборони. Порівняємо 3 міркуваннями Стуса, адресованими Свгенові Сверстюку в листі до батьків від 20 серпня 1974 року. Пишучи про власне заключення як фарс - самозахисна реакція, «аби не збожеволіти од нестерпного вогню» [2, с. 94], - Василь Стус водночас зауважує і його значущі переваги, саме звертається до категорії межі. «Отож, залишається призвикання до нових умов і перегляд старих уявлень про межі можливого. Але поза межами - теж, я б сказав, достобіса цікавого. Шкода тільки, - пише Стус, - що тяжко вириватися - $з$ усіма бебехами - в цей позамежний простір (правда, ще тяжче - не вириватися).

Час іде не намарне. Чую певне підростання, але про те боюся говорити, аби не омилитися. $<\ldots>$.

А при всьому тому - маю творчу відпустку, бо пообписувався вже 3-на весь термін, бо час зупинено на найкращій для творчості межі. Завжди - часГолготи - хто б не позаздрив цьому почуванню!» [2, с. 95]. Активізація творчого зусилля Василем Стусом сприймається як взаємозалежна від межової ситуації, в якій перебуває, звідси образ часу-Голготи (межа життя і смерті), асоційований із місцем страти Ісуса Христа. У книзі «Листи і люди» Михайлина Коцюбинська зауважує, що в листах Василя Стуса постійно звучить мотив перегляду меж можливого, долання бар'єрів і пов'язано це 3 його вмінням утвердитися в екстремальних умовах шляхом кристалізації постави чи то прямостояння [8, с. 137]. Вагомо, що біограф Дмитро Стус, приписуючи Стусовій життєтворчості ідею буття «на межі», «на постійному максимумі», «між життям і смертю» $[3$, с. 7,93$]$, таким чином влучно трактує взаємини письменника зі світом.

Найістотніше у такому взаємненні для Василя Стуса - реалізація власного креативного потенціалу, ядром якого психологія називає творчу 
обдарованість людини. Так, на думку стусознавця Сергія Несвіта, творчість, невіддільна від етики, давала змогу Стусові максимально самореалізуватися та була способом усвідомлення самого себе, тобто розумілася водночас як результат, процес, мета і шлях іï досягнення [9, с. 239]. 3 одного боку, творчість сприймається ним, людиною раціонального мислення, наполегливою і педантичною, інтелектуально відкритою до нового досвіду, як праця, ремесло з відповідними психологічними характеристиками (сильна концентрація, напруга уваги, інтуїція, асоціативна образна робота думки тощо) [10, с.43-58]. Так, у листі до дружини від 3-4 грудня 1975 року, коментуючи прочитаний драматичний твір «Граємо Стріндберга» Фрідріха Дюрренматта, Василь Стус оперує поняттям ремесла. Майстерно зроблений швейцарським письменником шедевр драматичного мистецтва, в якому вражає саме форма, блискуча подача, наводить Стуса на думку про ремесло як мистецтво: «умієш - зробиш» [2, с. 197].

3 іншого боку, Стус як водночас рефлективна людина сприймає творчість за несвідомий, мимовільний процес, зокрема так його описано в листі до дружини від 3 червня 1976 року: «Нудно мені сидіти на лікарні без книжок, за нудьгою місця не знайду. Вірші ж - саме збиткування: то починають іти, наче кров із горла, силоміць подержать коло себе і вже: накивали п’ятами, накидали оком - вибачаючись за короткі гостини, за пута приємні, за розлуку. I що зробиш? Мабуть, на цьому світі тільки й радості підставити свої руки під золотий потік натхнення - і пригубити води. Бо більшої втіхи немає» [2, с. 226]. Треба думати, Стусові йдеться про один із ключових етапів творчого процесу - осяяння (транссуб'єктивий стан натхнення), під час якого відбувається витіснення суб'єктивних чуттєвих ставлень до навколишнього світу (див.: [11, с. 36-38]).

Вирішальною умовою такого усвідомлення себе через творчість, розвитку вглибину для поета, судячи з численних згадок у листах до рідних $\mathrm{i}$ друзів, стає самотність. У листі до дружини і сина від 22 січня 1974 року читаємо: «Переваги мої тутешні: самота, спокій, самозосередження. Дасть Біг - 
усе це оплатиться віршами. Пошли, Боже, натхнення на мою стрижену голову!» [2, с. 67]. Творчого усамітнення / спокою / самоти / тиші як складової досконалості й словесного квітування, дослухаючись до Яна Парандовського [12, с. 109-110], неабияк потребувала інтровертна натура Стуса.

У листах до родини за 1974-1978 роки він пише про голод на самотність [2, с. 72], народження думок лише на самоті [2, с. 146], зменшення творчих імпульсів за браком самотності [2, с. 248], «великий голод на тишу!» [2, с. 262, 264], творчу самоту як навальну силу, якої щॄе мало [2, с. 295-296]. Епістолярії із селища Матросова і селища Кучино до товариського кола Олега Орача, Анни-Галі Горбач, подружжя Довганів, Свгена Сверстюка фіксують наполегливе Стусове прагнення самоти: «Живу в гуртожитку, але подумую про келію - творчу робітню. Хочу спокою, самотності, безоких стін і вікна» [5, с. 103]; «Це гуртожиток, із якого я збираюся дременути, винайму “куток”, де б міг мати творчу тишу 3 колимською атмосферою» [5, с. 105]; «Рито, дебати $з$ приводу синдромів полишімо - то мало користі, та й тема нудна. Вже якось перебуду - от би добутися до кутика затишного, де є Самотність - моя феєрична дружина, за якою я так знудився» [5, с. 107]; «Мабуть, я створений для самоти, в якій найкраще функціоную» [5, с. 181]. Беручи до уваги висловлене у листах, слід зазначити, що усамітнення розцінюється Стусом щонайменше як вагомий складник творчої роботи. Щонайбільше, беручи до уваги думку Сергія Несвіта, - як допоміжний засіб самопізнання, звідси характеристика літературознавцем Василя Стуса як самотнього естета [9, с. 232, 236].

\section{Висновки з цього дослідження і перспективи подальших розвідок у}

цьому напрямі. Отже, у випадку Василя Стуса наодинці відбувається вираження своєї мети і змісту - переважно в поетичних формах, що характерно для інтровертної людини, природною домінантою у внутрішньому світі якої виступає емоція [13, с. 418]. Саме розкриття інтровертної складової

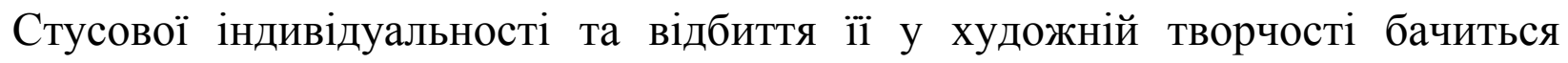
перспективою для подальших досліджень. 


\section{ЛІТЕРАТУРА}

1. Пуніна О. Характер Василя Стуса як основа психотипу письменника. Слово $i$ Час. 2019. № 10. C. 3-13.

2. Стус B. Твори: у 4 т., 6 кн. / ред. кол. С. Гальченко, М. Гончарук та ін. Львів: Просвіта, 1997. Т. 6. Кн. 1: Листи до рідних / упор. О. Дворко, М. Коцюбинська. 496 с.

3. Стус Д. Василь Стус: Життя як творчість. Київ: Факт, 2005. 368 с. $428 \mathrm{c}$.

4. Соловей О. Оборонні бої: статті, рецензії, есеї. Донецьк: Видавництво БВЛ, 2013.

5. Стус B. Твори: у 4 т., 6 кн. / ред. кол. С. Гальченко, М. Гончарук та ін. Львів: Просвіта, 1997. Т. 6. Кн. 2: Листи до друзів та знайомих / упор. О. Дворко, М. Коцюбинська. $264 \mathrm{c}$.

6. Нецензурний Стус. Книга у 2-х частинах. Частина 1 / упор. Б. Підгірного. Тернопіль: Підручники і посібники, 2002. 336 с.

7. Нецензурний Стус. Книга у 2-х частинах. Частина 2 / упоряд. Б. Підгірного. Тернопіль: Підручники і посібники, 2003. 320 с.

8. Коиюбинська М. Листи і люди. Роздуми про епістолярну творчість. Київ: Дух і Літера, 2009. 584 c.

9. Несвіт С. Морально-етичні домінанти В. Стуса в епістолярії. Молода нація: альманах [спецвипуск]: Василь Стус: Двадиять років після смерті: сучасне сприйняття $i$ переосмислення. 2006. Число 1 (38). С. 229-240.

10. Психология креативности: учебное пособие / Тодд Любарт [и др.]; пер. с фр. Д. В. Люсин. Москва: Когито-Центр, 2009. 214 с.

11. Пуніна О. Самітний геній: Олесь Ульяненко: літературний портрет. Київ: Академвидав, 2016. $288 \mathrm{c.}$

12. Парандовський Ян. Алхімія слова / пер. з пол. Ю. Попсуєнка. Київ: Дніпро, 1991. $374 \mathrm{c}$. $528 \mathrm{c}$.

13. Юнг К. Г. Психологические типы / пер. С. Лорие. Минск: ООО «Харвест», 2003.

\section{REFERENCES}

1. Punina, O. (2019). Kharakter Vasylya Stusa yak osnova psykhotypu pysmennyka [The character of Vasyl Stus as the basis of the psychotype of the writer]. Slovo $i$ Chas, (10), 3-13. [in Ukrainian].

2. Stus, V. (1997). Tvory [Works]. (Vol. 6. Part 1). Lviv: Prosvita. [in Ukrainian].

3. Stus, D. (2005). Vasyl Stus: zhyttya yak tvorchist [Vasyl Stus: Life as Creativity]. Kyiv: Fakt. [in Ukrainian].

4. Solovey, O. (2013). Oboronni boyi: statti, retsenziyi, eseyi [Defense battles: articles, reviews, essays]. Donetsk: Vydavnytstvo BVL. [in Ukrainian].

5. Stus, V. (1997). Tvory [Works]. (Vol. 6. Part 2). Lviv: Prosvita. [in Ukrainian].

6. Pidhirny, B. (Ed.). (2002). Netsenzurnyy Stus [Obscene Stus]. (Parts 1-2. Part 1). Ternopil: Pidruchnyky i posibnyky. [in Ukrainian].

7. Pidhirny, B. (Ed.). (2002). Netsenzurnyy Stus [Obscene Stus]. (Parts 1-2. Part 2). Ternopil: Pidruchnyky i posibnyky. [in Ukrainian].

8. Kotsyubynska, M. (2009). Lysty i lyudy. Rozdumy pro epistolyarnu tvorchist [Letters and People. Reflections on Epistolary Creativity]. Kyiv: Dukh i Litera. [in Ukrainian].

9. Nesvit, S. (2006). Moralno-etychni dominanty V. Stusa $v$ epistolyariyi [Moral and Ethical Dominants of V. Stus in Epistolary]. Moloda natsiya: almanakh [spetsvypusk]: Vasyl Stus: Dvadtsyat rokiv pislya smerti: suchasne spryynyattya i pereosmyslennya, (1), 229-240. [in Ukrainian].

10. Lyubart, Todd (Ed.). (2009). Psykholohyya kreatyvnosty [The psychology of creativity], trans. from French. Moskva: Kohyto-Tsentr. [in Russian]. 
11. Punina, O. (2016). Samitnyy heniy: Oles Ulyanenko [The lone genius: Oles Ulyanenko]. Kyiv: Akademvydav. [in Ukrainian].

12. Parandovskyy, Yan. (1991). Alkhimiya slova [Alchemy of the word], trans. from Polish. Kyiv: Dnipro. [in Ukrainian].

13. Yung, K. G. (2003). Psihologicheskie tipy [Psychological types]. Minsk: OOO "Harvest". [in Russian].

\begin{abstract}
АННОТАЦИЯ
Ольга Пунина. Оборонительная система Васыля Стуса: этика и творческий процесс.

В статье объект исследования - позиция обороны, в которой находился Васыль Стус как человек и творец. Эта позиция по отношению к реальному (социалистическому) миру расценена как позиция типичного интроверта. В основе сложившейся оборонной системы писателя положены два ключевых понятия - этика и творческий процесс.
\end{abstract}

Ключевые слова: этика, творческий процесс, интроверт, экспрессионист, эпистолярий, воспоминания.

\title{
ABSTRACT \\ Olga Punina. The defense system of Vasyl Stus: ethics and the creative process.
}

The concept of the "defense system» of man and writer Vasyl Stus is proposed in the article. The material for such research was Vasyl Stus's epistolary, the memories and the apt characteristics of his friends. The analysis is carried out on the border with Jung's analytical psychology, in particular his theory of psychotype. Key questions of the theory of psychotype: how man acts and orientates in the world? how does a person perceive an external stimulus? how does a person respond to this stimulus? It is about what is the individual identity of a person, which is manifested in his decisions, feelings, actions, assessments. In the case of Vasyl Stus's personality, the answer may be: Vasil Stus acts, perceives and reacts acutely, vulnerablely, expansively, focusing on internal personal factors and permanently defending himself on many levels: linguistic, mental, ideological, physical. The defense position in which Stus is in relation to the real world (the position of a typical introvert) forms his specific defense system - ethical, especially when considering the fact that he has to defend his own position throughout his life. In the case of Vasyl Stus, ethical maximalism is a well-defined imperative in the realm of ethics in general and one's own behavior. Basically it is about Vasyl Stus as a typical expressionist artist. Another perspective of Vasyl Stus defensive position is the creative process which, according to the metaphorical commentary of the writer, is his support in the conditions of constant defense. In the current circumstances, an artificially created subjective world, an artistic one where the inner reality is seen as much more important, becomes of great importance to Vasyl Stus. From a psychological standpoint, it is about the movement of the psychic energy of the author towards the inner world - the way the mechanism of introversion works. Prone to loneliness, the tacit and humble nature of Vasyl Stus in the situation of prisoner prison, the exile is as far removed from reality and focuses on his creative work as circumstances permit.

Key words: ethics, creative process, introvert, expressionist, letters, memories.

Стаття надійшла до редакиійної колегії 13.09.2019 р.

Рекомендована до друку 21.10.2019 р. 